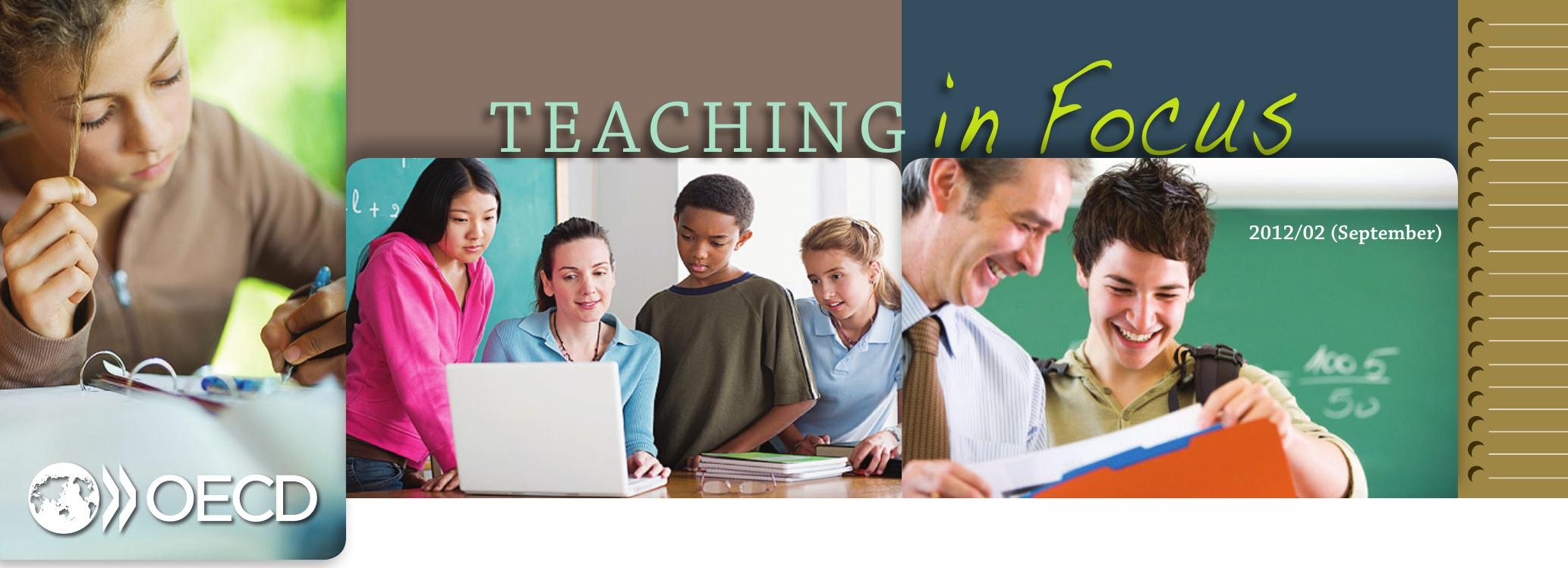

\title{
What Can Be Done to Support New Teachers?
}

- Schools are providing support for new teachers in the form of mentoring and induction programmes, but nearly one third of new teachers report a high level of need for professional development around student discipline and behaviour problems.

- Contrary to what is often reported, the schools in which new teachers teach are no different than those of their more experienced colleagues.

- According to the countries surveyed in the Teaching and Learning International Survey (TALIS), new teachers ${ }^{1}$ spend less time on teaching and learning and more time on classroom management and report lower levels of self-efficacy than experienced teachers.

\section{Many teachers start in the profession, but do not continue...}

New teachers face classrooms of students that are both exciting and overwhelming. Yet on average, nearly $10 \%$ of teachers in the first 1-3 years of their teaching leave the profession altogether, sometimes at a rate that is $150 \%$ higher than the attrition rate of other teachers (OECD, 2005). In order to facilitate the professional growth and success of new teachers, we need to understand their areas of need and how they can be assisted in achieving professional mastery. Providing this type of support may help keep new teachers teaching.

\section{What is TALIS?}

TALIS is the first international survey examining teaching and learning environments in schools. TALIS 2008 asked teachers and school principals in 24 countries about their work, their schools and their classrooms. (TALIS 2013 is currently being conducted in 33 countries.) This cross-country analysis helps countries identify others facing similar challenges and learn about their policies.

The information in this brief is largely from the report The Experience of New Teachers: Results from TALIS 2008.

More information at www.oecd.org/talis.

\section{New teachers are less confident in their ability to be effective teachers...}

Countries are examining the effectiveness of their new and experienced teachers alike, and many are also looking at how initial teacher training institutions are preparing teachers for the workforce. TALIS does not assess teacher effectiveness but asks teachers to report on their own feelings of self-efficacy. On average, new teachers report significantly lower levels of self-efficacy than their more experienced colleagues (see Figure 1). 
Figure 1 - Perceived self-efficacy of new and more experienced teachers

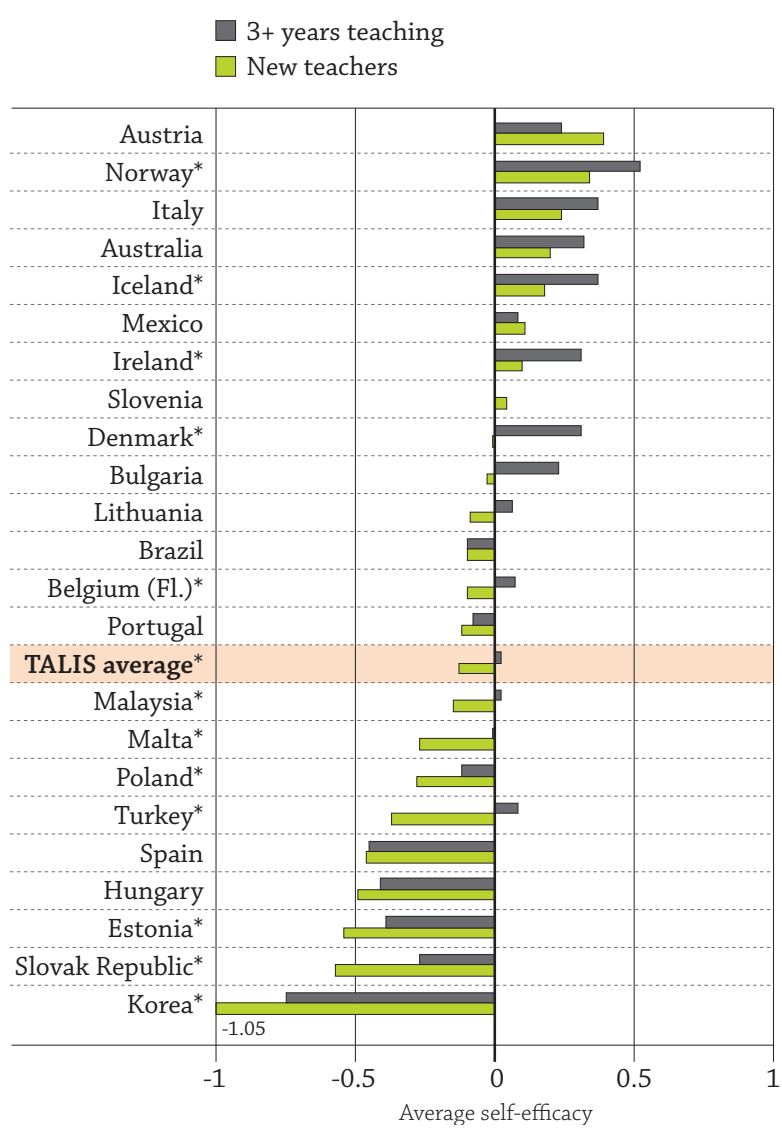

\section{What this means in practice}

Improving teachers' self-efficacy can improve classroom experiences for teachers and students and encourage the retention of new teachers in the profession. Things like classroom climate, professional development and feedback on practice, all discussed in this brief, can contribute to raising - or diminishing - a teacher's feelings of effectiveness.

\section{New teachers have similar working conditions to experienced teachers...}

In countries where new teachers are leaving the profession in great numbers, the attrition rate is often attributed to new teachers being placed in more challenging working conditions or harder-to-staff schools.

TALIS data shows that on average, new teachers have similar classrooms to more experienced teachers. There are nearly no differences in the language status or socioeconomic backgrounds of their students, and their schools have similar levels of material and personnel resources. In seven of the TALIS countries, new teachers have lighter teaching loads than experienced teachers, and only Australian new teachers have heavier schedules, on average. Half of the countries surveyed in TALIS help facilitate new teachers' success by providing them with significantly smaller-sized classrooms.

\section{What this means in practice}

Although new teachers aren't necessarily teaching in more difficult conditions than experienced teachers, they still feel less confident in their teaching ability. Rethinking a school's organisation to lighten the teaching loads of new teachers could allow more structured time for lesson planning, in-school support and classroom observation. 


\section{New teachers spend more time on classroom management and less time on teaching...}

In the classroom, new teachers say they spend considerably more time on classroom management than more experienced teachers (see Figure 2). On average, new teachers spend 9\% of their time on administrative tasks, $18 \%$ on keeping classroom order and management, and $73 \%$ on actual teaching and learning.

Figure 2 - Teaching time differences between new and more experienced teachers, by country

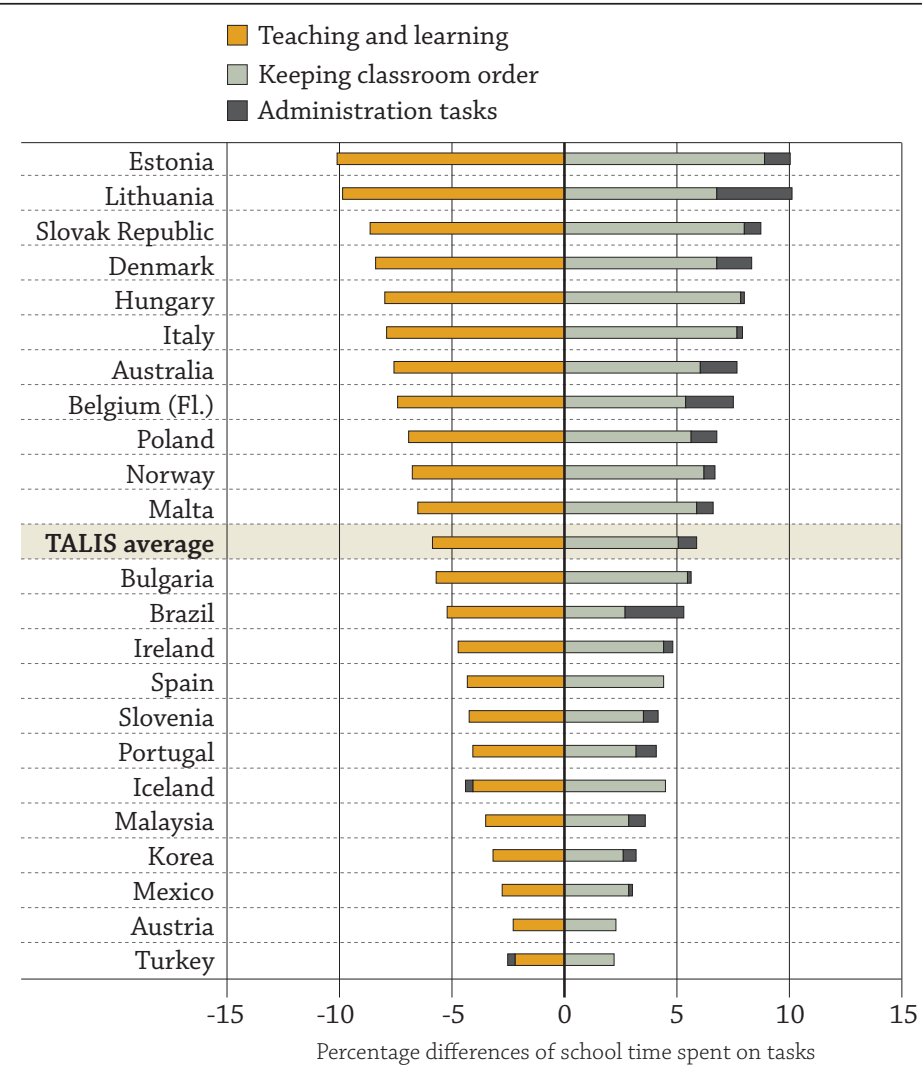

Source: OECD, TALIS Database. Teaching and Learning International Survey 2008.

More time spent on managing or discipline means less time spent teaching during a class period. One in 4 new teachers expresses a high need for professional development in student discipline and behaviour problems. Only 1 in 8 more experienced teachers expresses this same need.

\section{What this means in practice}

New teachers are aware of their classroom management needs and want to improve. School-based professional learning and development to improve classroom management skills could meet these needs and increase teaching and learning time.

\section{Many schools support new teachers from the start...}

Schools across TALIS countries are developing teacher mentoring and induction programmes as a way to support new teachers (see Figure 3). Three quarters of new teachers surveyed work in schools with mentoring and/or induction programmes. The quality of these programmes varies considerably; some are just administrative introductions while others are years-long partnership programmes. 
Figure 3 • Proportion of schools with new teacher induction programmes, by country

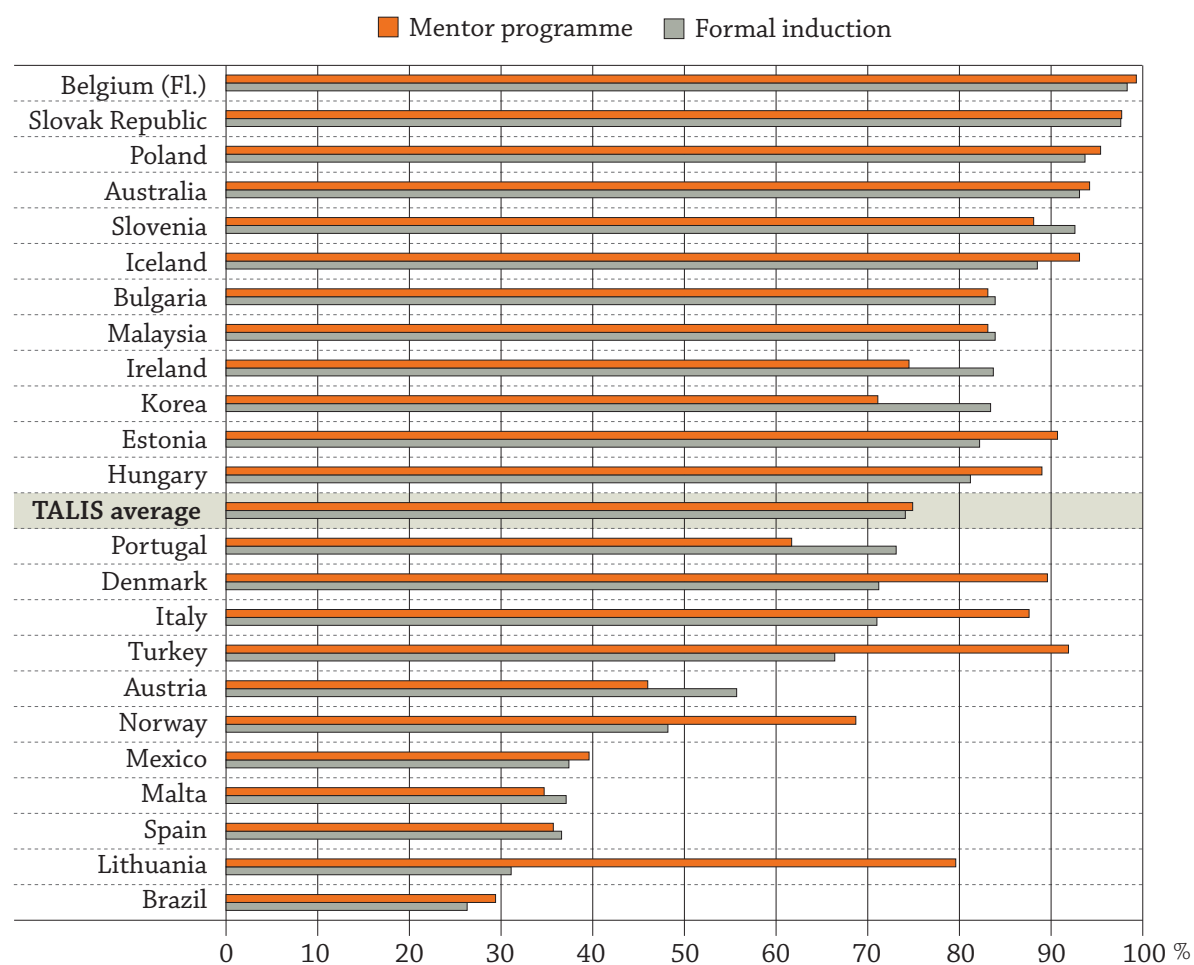

Source: OECD, TALIS Database. Teaching and Learning International Survey 2008.

Surprisingly, there doesn't seem to be any relationship between these programmes and new teachers receiving feedback on their teaching. More than half of new teachers in schools with induction or mentoring programmes reported only receiving feedback once a year or less. For new teachers who are eager to improve their teaching practice, schools could be missing an opportunity. New teacher feedback and appraisal does not have to be formal in evaluation and sanctioning, but it could provide much-needed professional development and additional support.

The bottom line It is true that much of the responsibility in preparing new teachers for the workforce lies with initial teacher training institutes and teacher preparation programmes. However, once a new teacher begins teaching, regardless of what his or her school or classroom situation looks like, there are ways that schools can provide more support. Lightening the teaching load, providing feedback from mentoring programmes and offering professional development around classroom management seem to be areas readily available to improve new teachers' self-efficacy and help boost their success.

\section{References}

OECD (2005), Teachers Matter: Attracting, Developing, and Retaining Effective Teachers, OECD Publishing.

\section{Visit}

www.oecd.org/talis
Contact:

Kristen Weatherby (Kristen.Weatherby@oecd.org)
To learn more

See The Experience of New Teachers: Results from TALIS 2008 